\title{
Disappearance of Forage Under Short Duration and Season- long Grazing
}

DONALD R. KIRBY, MARK F. PESSIN, AND GARY K. CLAMBEY

\section{Abstract}

A study was conducted in 1982 and 1983 at the Dickinson Experiment Station, North Dakota, in the mixed grass prairie to determine the effects of short duration grazing (SDG) and repeated seasonlong grazing (RSLG) by cattle on graminoid, forb, and half-shrub disappearance. Five range sites were delineated within each grazing treatment and evaluated for forage availability and disappearance. Graminoid disappearance was similar, regardless of grazing treatment, each year of the study. However, forb disappearance (i.e., utilization) increased three-fold in 1982 and more than two-fold in 1983 on the SDG treatment as compared to the RSLG treatment. Half-shrub availability and disappearance were negligible both years of the study. Spatial distribution of grazing among range sites on treatments must be evaluated with caution due to limitations in study design. Treatments were not equal-sized or replicated, and area, productivity potential, and distribution of range sites within treatments varied. Despite these limitations, no consistent pattern of site preference was discernible on either grazing treatment. In addition, a greater stocking rate (75\%) and density (1400\%) on the SDG treatment did not improve grazing distribution as measured by forage disappearance among the diverse range sites present.

Grazing management and systems have been the most important management practices implemented for improving rangelands (Kothmann 1980). Specialized systems such as short duration grazing have been hypothesized as contributing to range improvement by altering livestock distribution (Savory and Parsons 1980, Malecheck and Dwyer 1983). Defoliation patterns of native grass species by cattle have been reported for individual plants or plant parts under various grazing intensities (Gammon and Roberts 1978a, 1978b, 1978c; Hodgkinson 1980; Briske and Stuth 1982). Defoliation patterns among sites on grazed lands have generally emphasized specialized habitats or sites such as riparian (Johnson 1965, Bryant 1982, Gillen et al. 1985) and forested habitats (Hedrick et al. 1968, Miller and Krueger 1976, Roath and Krueger 1982, Gillen et al. 1984) or mountainous sites (Mueggler 1965, Cook 1966, Patton 1971). Information on the influence of grazing systems on cattle use among a variety of grassland plant communities (range sites) is lacking.

The objective of this study was to determine the effects of short duration (SDG) and repeated seasonlong cattle grazing (RSLG) on disappearance of plant classes and species on 5 range sites in the mixed grass prairie of western North Dakota.

\section{Materials and Methods}

The study was conducted on section 16 of the Dickinson Experiment Station approximately $35 \mathrm{~km}$ northwest of Dickinson, North Dakota. Average precipitation for the study area is $39 \mathrm{~cm}$, with $80 \%$ received between April and September. Total precipitation was 64 and $39.5 \mathrm{~cm}$ in 1982 and 1983 , respectively. Average daily temperature for the study area is $4^{\circ} \mathrm{C}$, with a high of nearly $27^{\circ} \mathrm{C}$ in July and a low of $-13^{\circ} \mathrm{C}$ in January. The growing season

\footnotetext{
Authors are assistant professor and research assistant, Animal and Range Sciences Department; and assistant professor, Department of Botany, North Dakota State University, Fargo, 58105.

The authors gratefully acknowledge Mr. Tom Conlon, superintendent, Dickinson Experiment Station, and Mr. Clayton Haugse, chairman, Animal and Range Sciences Department, North Dakota University, for their assistance in this study.

Published with the approval of the Director, North Dakota Agricultural Experiment Station TA-1479.

Manuscript accepted 7 July 1986.
}

averages 120 days (USDA, SCS 1982). The taxa represented were typical of the mixed-grass prairie (Whitman and Wali 1975).

Five range sites, thin claypan (Tcp), shallow (Sh), sandy (Sa), silty $(\mathrm{Si})$ and clayey $(\mathrm{Cl})$ (USDA, SCS 1982), comprised nearly all of section 16. Average forage production is $780,1,680,2,352,2,240$ and $2,240 \mathrm{~kg} / \mathrm{ha}$ for the Tcp, $\mathrm{Sh}, \mathrm{Sa}, \mathrm{Si}$, and $\mathrm{Cl}$ sites, respectively. The Tcp site is gently sloping with deep soil, but root and moisture penetration is restricted by a subsoil natric horizon at a depth of approximately $8 \mathrm{~cm}$. The Si site, located on the uplands, is composed of moderately deep to deep soils. Being on the uplands, the soils on this site are moderately well to well drained. Soils of the Sa site are moderately deep and well drained. This site is located on side slopes of uplands. The Sh range site is located on the uplands. Soils are shallow to moderately deep and well drained to excessively well drained. This site has very low available water capacity. The $\mathrm{Cl}$ range site is also located on uplands and is gently sloping. Soils on this site are moderately well drained to well drained. Total elevation difference between sites was approximately $35 \mathrm{~m}$ with slope varying from 0 to $10 \%$. Range condition was high fair to low good on all sites at the initiation of the study. The study area ( 3 paddocks) under the SDG treatment was comprised of 34, 21, 8, 18 , and $19 \%$, respectively, of the $\mathrm{Tcp}, \mathrm{Sh}, \mathrm{Sa}, \mathrm{Si}$, and $\mathrm{Cl}$ range sites, while the RSLG treatment was comprised of $12,32,4,20$, and $32 \%$, respectively, of the same sites.

\section{Grazing Treatments}

Section 16 was divided into 2 equal-sized grazing treatments in June 1981. Prior to this, the section was grazed seasonlong as part of a registered cattle operation. The western 130 ha were grazed continuously seasonlong. An 8-pasture, 1-herd short duration grazing system was implemented in the eastern 130 ha, with the 8 equal-sized paddocks radiating out from a central water and handling facility. The paddocks were managed on a 5-day graze and 35-day rest schedule throughout the grazing season on SDG paddocks. Each paddock in the SDG treatment was grazed 3 to 4 times per season depending upon the length of the grazing season. Stocking rate was $20 \mathrm{cow} /$ calf pairs $(0.67 \mathrm{AUM} / \mathrm{ha})$ on the RSLG treatment, as recommended by SCS guidelines, and $35 \mathrm{cow} /$ calf pairs (1.2 AUM/ha) on the SDG treatment. Grazing was initiated June 22 and 17 and terminated October 12 and 26 in 1982 and 1983, respectively, concluding 112 and 131 day grazing seasons.

\section{Forage Production and Disappearance}

The 5 range sites were delineated within each grazing treatment (3 adjacent paddocks on the SDG treatment) and 10 portable exclosures were randomly allocated at each site on both grazing treatments. Each range site was chosen between 200 to $600 \mathrm{~m}$ from a watering point. Availability of graminoids, forb, and half-shrub by class and species was estimated at the initiation and termination of grazing trials and every $\mathbf{4 0}$ days during the trials by clipping two $0.25-\mathrm{m}^{2}$ plots in each exclosure. Forage samples were oven-dried and availability reported on a dry weight basis. Exclosures were moved following each sampling. Forage disappearance was estimated by clipping 20 uncaged $0.25-\mathrm{m}^{2}$ plots on each site of each treatment. Each uncaged plot was "paired" with a caged plot following each availability estimate. The difference in dry weight between each caged and uncaged paired plot was summed and used to estimate percent forage disappearance.

T-tests were used to determine differences in total graminoid, forb, and half-shrub availability and disappearance between sim- 
ilar range sites on the 2 grazing treatments (Steel and Torrie 1960).

\section{Results}

Precipitation for the 2 study years was highly variable. In 1982, $64 \mathrm{~cm}$ of precipitation were recorded for the year with almost $18 \mathrm{~cm}$ falling during May and early June and over $16 \mathrm{~cm}$ falling in late October and November. The following year, 1983, was near average with $39.5 \mathrm{~cm}$ of precipitation recorded for the year and only 12 $\mathrm{cm}$ falling during May and early June. Because of these differences, data for the 2 years were analyzed separately.

Availability and disappearance of the 3 classes of forage were summarized by year, site, and grazing treatment (Table 1). Comparison of forage availability on corresponding sites between the grazing treatments indicated similar availabilities with 3 exceptions. The Si site in 1982 and the $\mathrm{Si}$ and $\mathrm{Cl}$ sites in 1983 had significantly more forage available on the RSLG treatment than the SDG treatment.

Graminoid and total herbaceous availability increased on both grazing treatments from 1982 to 1983 . Several conditions led to this increase. Despite receiving above-average growing season precipitation in 1982, spring growth on both treatments was retarded from the lack of soil moisture stored from a dry $1981(21.5 \mathrm{~cm}$ precipitation). Following the growing season in 1982, over $16 \mathrm{~cm}$ precipitation was received between October and December and presumably stored in the soil. This previously stored soil moisture coupled with the near-average precipitation received in 1983 resulted in favorable growing conditions as evidenced by the increased graminoid availability in 1983 when compared to 1982 (Table 1).

In contrast, forb and half-shrub availability decreased from 1982 to $\mathbf{1 9 8 3}$ on both grazing treatments. The timing of growing season precipitation may account for this. Plentiful May and June precipitation was received in 1982 resulting in strong growth of broadleaved herbaceous plants. Early season precipitation fell sparingly in 1983 . Broad-leaved herbaceous plants did not respond well to this delayed spring-summer precipitation (Table 1).

Mean graminoid disappearance $(\%)$ was similar, between the 2 grazing treatments, each year of the study (Table 1). However, percentage forb disappearance was three-fold higher in 1982 and more than two-fold higher in 1983 on the SDG when compared to the RSLG. Interestingly, despite the drop in forb production, percentage forb disappearance was similar on both grazing treatments from year to the next. Half-shrub production was negligible both years and does not warrant further discussion.

Total forage disappearance $(\%)$ was similar between the 2 grazing treatments each year, despite the SDG treatment being stocked at a $75 \%$ greater rate. The increased disappearance on both grazing treatments from 1982 to 1983 was a reflection of the decreased forb availability from one year to the next.

Of the 3 forage classes, graminoids were the major forage available and had the highest percentage disappearance (i.e., utilization) throughout the study period regardless of grazing treatment (Table 2). Graminoid availability increased on range sites from 1982 to 1983 over both grazing treatments, with the exception of the Tcp site on the RSLG treatment. Graminoids contributing significantly both years to forage on grazing treatments were the cool-season wheatgrasses (Agropyron spp.), needlegrasses (Stipa spp.), and sedges (Carex spp.), and the warm-season short grass blue grama (Bouteloua gracilis (H.B.K.) Lag. ex Steud). In addition, coolseason short grasses, mainly junegrass (Koeleria pyramidata (Lam.) Beauv.), contributed greatly to production and disappearance in 1983.

Over the study period, significant differences were determined in availability of graminoids between similar range sites on the $\mathbf{2}$ grazing treatments (Table 2). In 1982 significantly more graminoids were available on the Si site of the RSLG treatment when compared to the same site on the SDG treatment. The Si and $\mathrm{Cl}$ sites on the RSLG treatment in 1983 were evaluated as having significantly greater graminoid availability when compared to the similar sites in the SDG treatment. These differences are a result of selection of sampling sites at the initiation of the trial and should not be attributed to grazing treatment.

Significant differences in graminoid disappearance were found between the 2 grazing treatments on most sites (Table 2). In 1982, graminoid disappearance was significantly higher on the Tcp and Si sites and significantly lower on the Sa site of the SDG treatment when compared to the RSLG treatment. The following year, 1983, graminoid disappearance was significantly higher on the $\mathrm{Sa}$ and $\mathrm{Cl}$ and significantly lower on the Sh and Si range sites of the SDG treatment when compared to the RSLG treatment.

Percentage graminoid disappearance also varied greatly each year between range sites within grazing treatments (Table 2). Graminoid disappearance during 1982 ranged from 22 to $50 \%$ among sites on the SDG treatment and 7 to $57 \%$ on the RSLG treatment. Only 1 site, the Tcp in the RSLG treatment, was determined as being nearly unutilized. Graminoid disappearance was only $7 \%$ on this site in 1982 . During 1983 graminoid disappearance ranged

Table 1. Availability ( $\mathrm{kg} / \mathrm{ha}$ ) and \% disappearance in parentheses of forage on five range sites grazed under short duration (SDG) and repeated seasonlong (RSLG) grazing treatments on the Dickinson Experiment Station.'

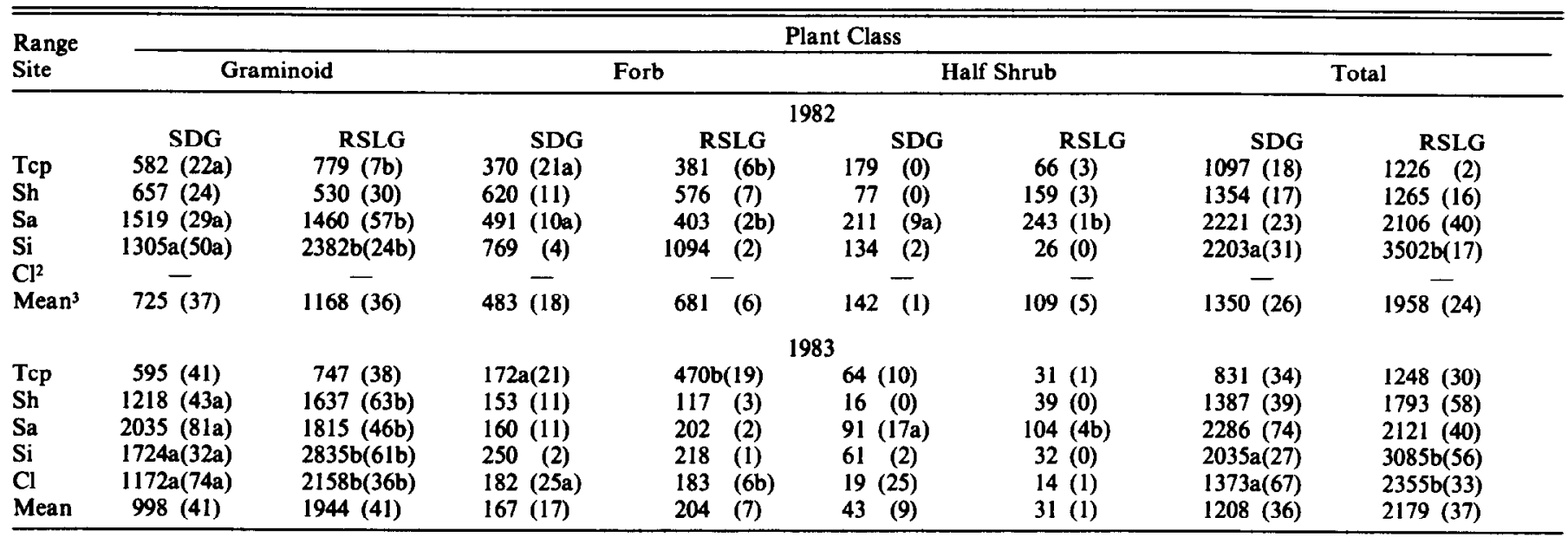

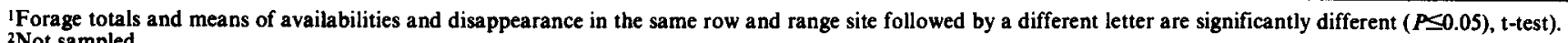
2 Not sampled.

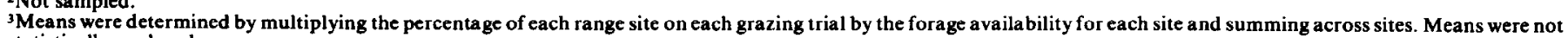
statistically analyzed. 
Table 2. Avallability ( $\mathrm{kg} / \mathrm{ha}$ ) and $\%$ disappearance in parentheses by species of forage on five range sites for short duration (SDG) and repeated seasonlong (RSLG) graxing treatments on the Dickinson Experiment Station.

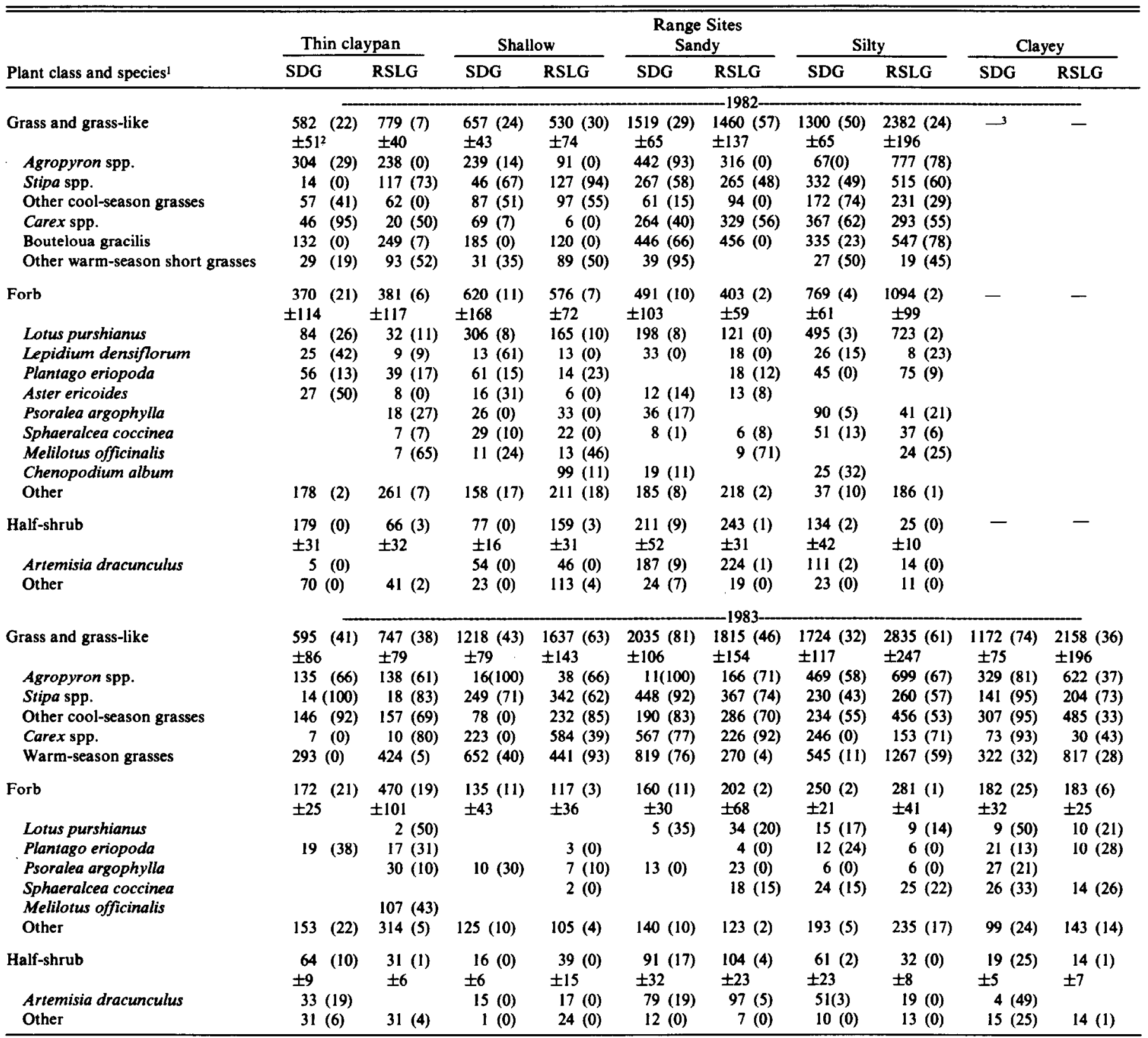

'Scientific names follow Great Plains Flora Association (1977) or more recent taxonomic considerations.

2Standard error of the mean.

${ }^{3}$ Not sampled.

from 32 to $81 \%$ among range sites on the SDG treatment and 36 to $63 \%$ on the RSLG treatment. In contrast to 1982 , cattle utilized a more uniform amount of graminoid species on all sites over both grazing treatments in 1983.

Forb availability declined from 1982 to 1983 on all range sites in both grazing treatments (Table 2). No significant differences in total availability of forbs occurred in 1982 between similar range sites on the 2 grazing treatments. In 1983 only 1 site, the Tcp on the RSLG treatment, was found to have significantly more forb availability than the corresponding site in the SDG treatment. Forb availability was greatest both years on the $\mathrm{Si}$ range sites from both grazing treatments, despite these sites having the least diversity of forb species (26). The Sh sites in 1982 and the Tcp sites in 1983 on both treatments produced a significant quantity of forbs besides having the greatest diversity of forbs, 32 and 34 species, respectively.

Few individual forbs consistently contributed to herbaceous production on range sites. Only prairie bird's-foot trefoil (Lotus purshianus Clem. \& Clem.), silver-leaf scurfpea (Psoralea argophylla Pursh), red false mallow (Sphaeralcea coccinea (Pursh) Rydb.), and alkali plantain (Plantago eriopoda Torr.) were present both years on the majority of sites for both treatments (Table 2). Peppergrass (Lepidium densiflorum Schrad.) and white aster (Aster ericoides L.) also contributed significantly to forb availability in 1982.

Total forb disappearance in both years was higher for each site in the SDG treatment when compared to the corresponding site in the RSLG treatment (Table 2). However, significantly higher disappearance of forbs on SDG sites occurred only on the Tcp and Sa range sites in 1982 and the $\mathrm{Cl}$ site in 1983. In 1982, total forb disappearance exceeded $10 \%$ on 3 of 4 range sites monitored on the SDG treatment, while no sites on the RSLG treatment exceeded $10 \%$ forb usage. Also in 1983 , total forb disappearance exceeded 
$10 \%$ on 4 of 5 range sites examined on the SDG treatment, while only 1 site on the RSLG treatment exceeded $10 \%$ forb use.

Of the 27 forb species occurring in common on the corresponding range sites between grazing treatments in 1982, over $60 \%$ showed greater disappearance on the SDG treatment (Table 2). In comparing percentage disappearance of the 24 common forb species in $1983,75 \%$ had higher percentage disappearance on the SDG treatment when compared to the RSLG treatment.

Half-shrub availability was limited on all sites and treatments in 1982 and less on all sites and treatments in 1983 when compared to 1982 (Table 2). No differences in availability of half-shrubs were determined in either year between range sites on the 2 grazing treatments. The Sa site both years produced the most half-shrubs, mainly green sage (Artemisia dracunculus L.), on the 2 grazing treatments.

Significant differences in disappearance of half-shrubs were determined both years only for the Sa site on grazing treatments (Table 2). More half-shrub disappearance, mainly green sage, occurred on the SDG treatment when compared to the RSLG treatment.

\section{Discussion}

Graminoids were the major forage available and had the greatest percentage disappearance (i.e., utilization) throughout the study regardless of grazing treatment. These results were not unexpected as cattle diets have generally been reported as being comprised mainly of graminoid species (Cook and Harris 1968, Rosiere et al. 1975, Allison et al. 1977, Kirby and Stuth 1982). The major graminoids available and contributing to livestock production were the wheatgrasses, needlegrasses, blue grama and other warm-season shortgrasses, and sedges.

Forbs and half-shrubs in addition to graminoids can be important contributors to cattle diets, especially early in the grazing season (Thetford et al. 1971, Buchanan et al. 1972, Allison and Kothmann 1979, Uresk and Paintner 1985). However, when dealing with forbs and half-shrubs at the species level in studies such as this, results are less conclusive because of annual variations in growth. In addition difficulties are also encountered in matching forb and half-shrub species composition in paired plots. These problems limit conclusions at the species level.

Forb diversity among range sites ranged from 26 to 34 species. Despite this diversity few individual species were grazed in quantity by cattle on either grazing treatment. Prairie bird's-foot trefoil, lamb's quarters (Chenopodium album L.), and yellow sweet clover (Melilotus officinalis (L.) Lam.) were the only forbs available in quantity and utilized consistently over the trial by cattle. Less consistently red false mallow, alkali plantain, and white aster were utilized by cattle on the grazing treatments.

Interpretation of grazing distribution among sites within and between treatments is made difficult by the study design. In the design grazing treatments were not replicated, pasture size and the percentages of high and low forage producing sites and their spatial relationship varied between treatments, and stocking rate and density also differed between treatments. Despite these limitations, spatial distribution of grazing requires discussion.

No consistent pattern of site preference was discernible from our data. Percentage graminoid and forb disappearance among sites within grazing treatments, and between similar sites across grazing treatments, showed no consistent trend. These results might not be unexpected as all study sites were dominated by graminoid species, easily accessible, and near watering points.

Increased stocking density has been associated with improved livestock grazing distribution in intensively managed grazing systems (Kothmann 1980). Despite the confounding of results by unequal pasture sizes, a greater stocking rate $(75 \%)$ and density $(1400 \%, 2.15$ vs. 0.15 animals/ha) did not improve grazing distribution as measured by forage disappearance among the various range sites under our SDG trcatment when compared to a conven- tional RSLG treatment. In 1982, grazing distribution among sites was more uniform on the SDG treatment when compared to the RSLG treatment. The reverse was observed in 1983. Stocking densities greater than were studied in our SDG design may improve distribution of grazing among diverse range sites. This will need further investigation.

\section{Literature Cited}

Allison, C.D., and M.M. Kothmann. 1979. Effect of level of stocking pressure on forage intake and diet quality of range cattle. Proc. West. Sec. Amer. Soc. Anim. Sci. 30:174-178.

Allison, C.D., R.D. Pieper, G.D. Donart, and J.D. Wallace. 1977. Fertilization influences cattle diets on blue grama range during drought. $J$. Range Manage. 30:177-180.

Briske, D.D., and J.W. Stuth. 1982. Tiller defoliation in a moderate and heavy grazing regime. J. Range Manage. 35:511-514.

Bryant, L.D. 1982. Response of livestock to riparian zone exclusion. J. Range Manage. 35:780-785.

Buchanan, H., W.A. Laycock, and D.A. Price. 1972. Botanical and nutritive content of the summer diet of sheep on a tall forb range in southwestern Montana. J. Anim. Sci. 35:423-430.

Cook, C.W. 1966. Factors affecting utilization of mountain slopes by cattle. J. Range Manage. 19:200-204.

Cook, C.W., and L.E. Harris. 1968. Nutritive value of seasonal ranges. Utah Agr. Exp. Sta. Bull. 472.

Gammon, D.M., and B.R. Roberts. 1978a. Patterns of defoliation during continuous and rotational grazing of the Matopos Sandveld of Rhodesia. I. Selectivity of grazing. Rhod. J. Agr. Res. 16:117-131.

Gammon, D.M., and B.R. Roberts. 1978b. Patterns of defoliation during continuous and rotational grazing of the Matopos Sandveld of Rhodesia. 2. Severity of defoliation. Rhod. J. Agr. Res. 16:133-145.

Gammon, D.M., and B.R. Roberts. 1978c. Patterns of defoliation during continuous and rotational grazing of the Matopos Sandveld of Rhodesia. 3. Frequency of defoliation. Rhod. J. Agr. Res. 16:147-164.

Gillen, R.L., W.C. Krueger, and R.F. Miller. 1984. Cattle distribution on mountain rangeland in northeastern Oregon. $J$. Range Manage. 37:549-553.

Gillen, R.L., W.C. Krueger, and R.F. Miller. 1985. Cattle use of riparian meadows in the Blue Mountains of northeastern Oregon. J. Range Manage. 38:205-209.

Great Plains Flora Association. 1977. Atlas of the flora of the Great Plains. T.M. Barkley (ed.) lowa State Univ. Press, Ames.

Hedrick, D.W., J.A. Young, J.A.B. McArthur, and R.F. Keniston. 1968. Effects of forest and grazing practices on mixed coniferous forests of northeastern Oregon. Oregon Agr. Exp. Sta. Tech. Bull. 103.

Hodgkinson, K.C. 1980. Frequency and extent of defoliation of herbaceous plants by sheep in a foothill range community in northern Utah. J. Range Manage. 33:164-169.

Johnson, W.M. 1965. Rotation, rest-rotation, and season-long grazing on mountain range in Wyoming. USDA Forest Serv. Res. Pap. RM-14.

Kirby, D.R., and J.W. Stuth. 1982. Botanical composition of cattle diets grazing brush managed pastures in east-central Texas. J. Range Manage. 35:434-436.

Kothmann, M.M. 1980. Evaluation of livestock needs on designing grazing systems for rangeland. Chap. 6 Part B. In: Digestive Physiology and Nutrition of Ruminants, D.C. Church (ed.), Vol. 3 O \& B Books, Inc. Corvallis, Ore.

Malechek, J.C., and D.D. Dwyer. 1983. Short-duration grazing doubles your livestock? Utah Sci. 44:32-37.

Miller, R.F., and W.C. Krueger. 1976. Cattle use on summer foothill rangelands in northeastern Oregon. J. Range Manage. 29:367-371.

Mueggler, W.F. 1965. Cattle distribution on steep slopes. J. Range Manage. 18:255-257.

Patton, W.W. 1971. An analysis of cattle grazing on steep slopes. M.S. Thesis, Brigham Young Univ., Provo, Utah.

Roath, L.R., and W.C. Krueger. 1982. Cattle grazing and behavior on a forested range. J. Range Manage. 35:332-338.

Rosiere, R.E., R.F. Beck, and J.D. Wallace. 1975. Cattle diets on semiarid grassland: Botanical composition. J. Range Manage. 28:89-93.

Savory, A., and S. Parsons. 1980. The Savory grazing method. p. 215-221. In: Beef Cattle Science Handbook, M.E. Ensminger (ed.), Vol. 17.

Steel, R.D.G, and J.H. Torrie. 1960. Principles and procedures of statistics. McGraw-Hill, Inc. New York.

Thetford, F.O., R.D. Pieper, and A.B. Nelson. 1971. Botanical and chemical composition of cattle and sheep diets on pinyon-juniper grassland range. J. Range Manage. 24:425-431. 
U.S.D.A., S.C.S. 1982. Soil survey of Dunn County, North Dakota

Uresk, D.W., and W.W. Paintner. 1985. Cattle diets in a ponderosa pine forest in the northern Black Hills. J. Range Manage. 38:440-442.
Whitman, W.C., and M.K. Wali. 1975. Prairie: A multiple view. Univ. N.D. Press, Grand Forks. 